\title{
Bulb Canker of Garlic Caused by Embellisia allii, Newly Found in Nepal
}

\author{
Ram D. Timila, Gyanu Manandhar and Sharada Joshi \\ Plant Pathology Division, Nepal Agricultural Research Council, Khumaltar, Lalitpur
}

Garlic (Allium sativum L.) is one of the mostly used spice crops of Nepal. Basically it is cultivated for bulbs as spice and young plants for leafy vegetables. The distinctive flavor of the genus, Allium is due to volatile sulfur compounds that are produced when plant tissues are bruished or cut. That sulfur compounds has the antimicrobial characteristics. It may also help to prevent cardiovascular and arteriosclerosis diseases (Schwartz and Mohan 1996).

Recently, a new disease, bulb canker or skin blotch of garlic has appeared in one of the farmer's fields at Bhaktapur (1400 masl) during March 2007. The variety of garlic was Chinese lasun. The local variety was found less affected in the field (as observed in the field). The bulb samples received from some locations of Sindhupalchowk district were also found to be infected.

Symptoms appeared as irregular lesions of dark layer underneath the epidermis which was as described by David (1991). The dark areas are developed due to powdery mycelia and conidia of the organism scattered on the outer scales of the developing garlic (Figure 1) or usually near the base of the bulb (Figure 2). Dark areas were also found on the backs and sides of the cloves within a head or on the edges of cloves (Figure 3). Field observations showed the yellowing of the plants (as observed recently in the field). The symptoms in the field appeared after watering followed by few days rain. The disease is reported to be a problem in wet years (Embellisia/OSU Plant Clinic 2007).

Infected plants and bulbs were collected and examined at Plant Pathology Division, Nepal Agricultural Research Council, Khumaltar, Nepal. Sign and symptoms were verified and studied with the help of cited literatures (Embellisia/OSU Plant Clinic 2007, David 1991) and under stereomicroscope as well as under compound microscope. The fungus was identified on the basis of conidial structure, secondary conidiophore (Ellis 1976). The conidia were ellipsoidal or subcylindrical, mid to dark brown smooth with 3-6 thick transverse septa with or without 1or 2 oblique or longitudinal septa (Figure 4). The colonies were effuse blackish brown to black on Potato dextrose agar medium. After symptomatology study and laboratory examination of characteristic conidial structures, the causal organism was found to be a fungus, Embellisia allii (Campanile) EG Simmons, (Synonym Helminthosporium alli Campanile).The fungus is reported to be overwintering in the plant debris, soil and infected bulbs (David 1991). 


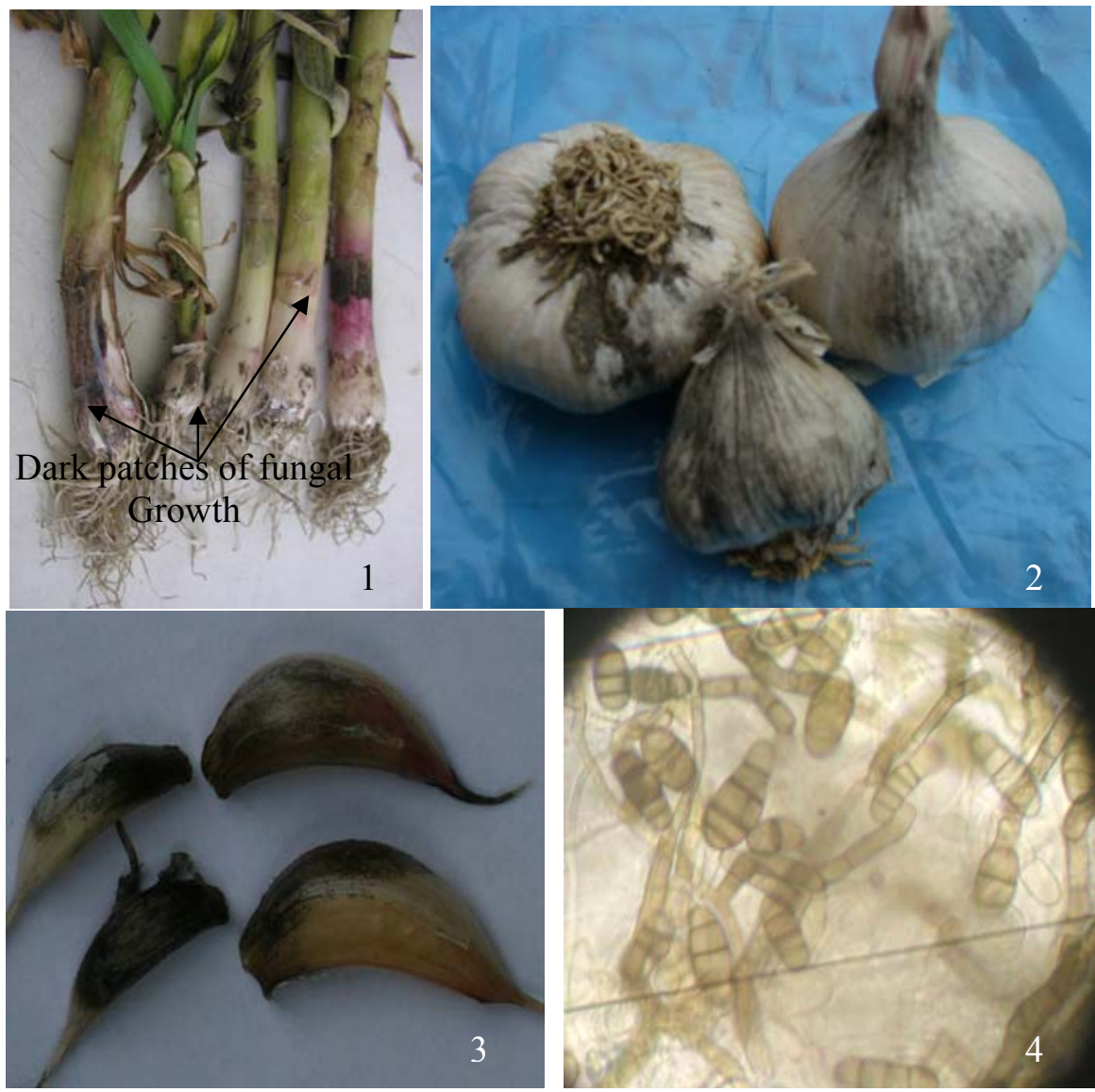

Figure 1. Infected garlic plants from the field showing dark patches on developing scales. 2. Canker on outer scale of bulbs. 3. Infected individual cloves. 4. Conidia of the fungus, $I F$. allii with dark transverse septa.

On follow up in the field observations, according to the farmer, total loss had occurred due to bulb canker and failed to harvest bulbs. E. allii has been reported pathogenic to garlic in the USA also (Dugan and Lupien 2006). This fungus is of quarantine concern in India because of chances of affecting domestic and international trade of this particular crop. Several consignments from China were stuck at the Mumbai Port and in Chennai, over 20 containers each with 14 tonnes of garlic have been stopped (The Hindu Business Line 2005).

In Nepal, cultivation of Chinese garlic (lasun) is increasing among the farmers of Nepal. That exotic variety has been observed to be more susceptible than the local variety (as observed in the farmers' field and the bulb samples received in the Laboratory. However, mild symptoms have also been observed in the bulbs of local variety.

For the management of bulb canker of garlic, some tactics have been suggested such as peeling off the discoloured outer scales of garlic heads, maintaining low humidity in storage, avoiding visibly diseased garlic bulbs in storage and wrapping garlic in breathable materials for marketing (Embellisia/OSU Plant Clinic 2007). In field conditions, maintaining good drainage and burning crop stubbles might be helpful in managing this disease.

So far, at the moment the disease was found in one of the farmers' field only, it may be spread in congenial conditions. It may affect the trade regarding the requirements of World Trade Organization concerning the pests of garlic. Hence, survey of this disease in commercially garlic growing areas is essential to find out the status of this disease. This is the first report on the occurrence of garlic bulb canker in Nepal. 


\section{REFERENCES}

David JC. 1991. Embellisia allii. IMI descriptions of fungi and bacteria, 1991(No.108) Sheet 1078. CAB Abstract.

Dugan FM and SL Lupien. 2006. Survey of pathogenic fungi in commercial seed garlic. USDA-ARS Western Regional Plant Introduction Station, Washington State University, Pullman, WA 99164-6402.

Ellis MB. 1976. More dematiaceous hypomycetes. Common Wealth Mycological Institute CAB. The Cambrian News Ltd. Aberystwyth. 507p.

Embellisia/OSU Plant Clinic. 2007. Embellisia skin blotch on stored garlic. http://www.bcc.orst.edu/bpp/plant_Clinic/Garlic/embellisia.htm.

Schwartz HF and SK Mohan. 1996. Compendium of onion and garlic diseases. APS Press. The American Phytopathological Society. 54p.

The Hindu Business Line. 2005. Garlic imports from China stopped on fungal infection. http://www.thehindubusinessline.com/2005/09/14/stories/2005091401981200.htm. 